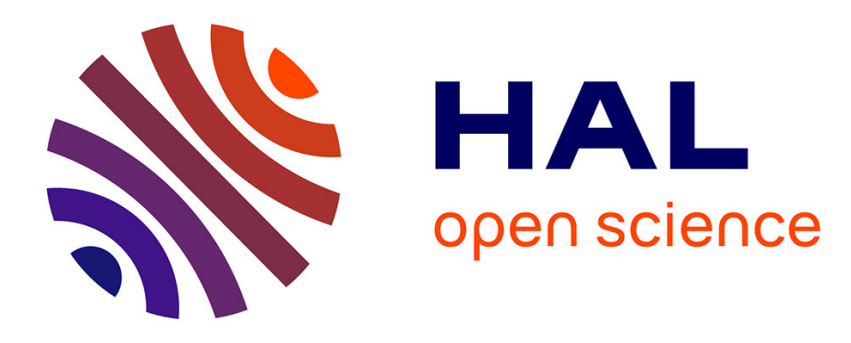

\title{
Market timing and corporate capital structure: a transatlantic comparison
}

\author{
Allard Bruinshoofd, Leo de Haan
}

\section{To cite this version:}

Allard Bruinshoofd, Leo de Haan. Market timing and corporate capital structure: a transatlantic comparison. Applied Economics, 2011, pp.1. 10.1080/00036846.2011.581211 . hal-00716627

\section{HAL Id: hal-00716627 \\ https://hal.science/hal-00716627}

Submitted on 11 Jul 2012

HAL is a multi-disciplinary open access archive for the deposit and dissemination of scientific research documents, whether they are published or not. The documents may come from teaching and research institutions in France or abroad, or from public or private research centers.
L'archive ouverte pluridisciplinaire HAL, est destinée au dépôt et à la diffusion de documents scientifiques de niveau recherche, publiés ou non, émanant des établissements d'enseignement et de recherche français ou étrangers, des laboratoires publics ou privés. 


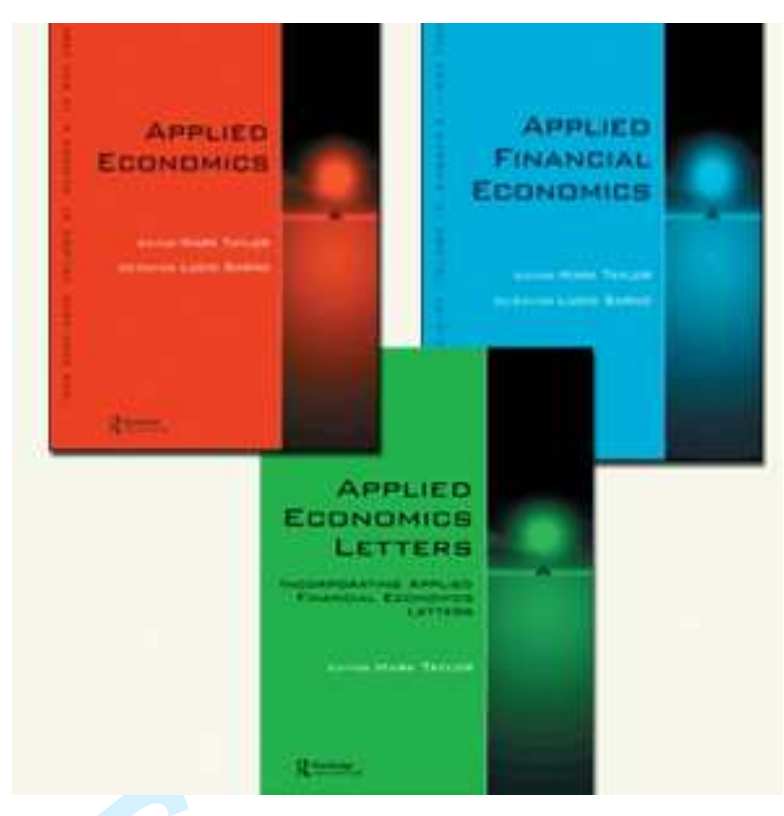

\section{Market timing and corporate capital structure: a transatlantic comparison}

\begin{tabular}{|c|c|}
\hline Journal: & Applied Economics \\
\hline Manuscript ID: & APE-08-0383.R1 \\
\hline Journal Selection: & Applied Economics \\
\hline $\begin{array}{r}\text { Date Submitted by the } \\
\text { Author: }\end{array}$ & 06-Apr-2011 \\
\hline Complete List of Authors: & $\begin{array}{l}\text { Bruinshoofd, Allard; Rabobank, Economic Research } \\
\text { De Haan, Leo; De Nederlandsche Bank, Economic Policy and } \\
\text { Research }\end{array}$ \\
\hline JEL Code: & $\begin{array}{l}\text { C33 - Models with Panel Data < C3 - Econometric Methods: } \\
\text { Multiple/Simultaneous Equation Models < C - Mathematical and } \\
\text { Quantitative Methods, G30 - General < G3 - Corporate Finance and } \\
\text { Governance < G - Financial Economics }\end{array}$ \\
\hline Keywords: & Market timing, Capital structure, ICT, International comparison \\
\hline
\end{tabular}

\section{SCHOLARONE \\ Manuscripts}




\title{
Market timing and corporate capital structure:
}

\section{A transatlantic comparison*}

\author{
W. Allard Bruinshoofd ${ }^{\mathrm{a}, *}$ \\ ${ }^{a}$ Rabobank, Utrecht, The Netherlands \\ Leo de Haan ${ }^{\mathrm{b}}$ \\ ${ }^{b}$ De Nederlandsche Bank, Economics and Research Division, Amsterdam, The Netherlands
}

April 2011

\begin{abstract}
This paper provides comparative international evidence on the effect of market timing on corporate capital structures using panel data for US, UK, and continental European firms. We document that the empirical regularity found for US firms, that historical market-to-book ratios and corporate leverage correlate negatively, does not extend to UK and continental European firms. The latter tend to raise debt rather than equity when stock prices are high, thus sticking more closely to a pecking order in which debt is preferred over external equity.
\end{abstract}

JEL codes: C33, G32

Keywords: Market Timing, Capital Structure, Pecking order

* Corresponding author. E-mail: w.a.bruinshoofd@rn.rabobank.nl 


\section{Introduction}

According to Baker and Wurgler's (2002, henceforth BW) market timing theory of corporate capital structure, leverage ratios of nonfinancial firms are the cumulative result of past attempts to time the equity market by issuing equity when stock prices are high. BW measure market timing by the external finance-weighted average of historical market-to-book ratios. They find that US firms' leverage ratios are significantly and negatively related to this market timing measure, which they interpret as evidence of the market timing theory. Their findings inspired a growing number of studies testing the consequences of equity market timing on capital structure. For instance, Hovakimian (2006) and Kayhan and Titman (2007) confirm the negative effect of historical market-to-book ratios on US corporate leverage, but do not corroborate its long-term persistency. Alti (2006) and Leary and Roberts (2005) show that US firms actively rebalance their leverage to stay within an optimal range, so that effects of market timing and other shocks are temporary. Welch (2004), on the other hand, demonstrates that US firms do not counteract the mechanistic influences of stock valuation on debt/equity ratios.

The studies cited above derive their empirical results from US data sets. The evidence for non-US firms on the impact of market timing on corporate capital structures is scarce and mixed. Högfeldt and Oborenko (2005), Mendes et al. (2005), Hegge (2006) and De Bie and De Haan (2007) do not find a significant relation between BW's market timing measure and leverage for Sweden, Brasil, the Netherlands, and Belgium, respectively. On the other hand, Mahajan and Tartaroglu (2008) report a negative relation for the G-7 countries, but find that this negative relationship cannot be attributed to equity market timing.

It is no coincidence that the attention for market timing came up soon after one of the biggest boom-bust cycles on the international stock exchanges of the last decades: the 'internet boom' in the second half of the 1990s. This boom was particularly evident in the valuation of stocks for information and communication technology (ICT) firms. This raises the question of whether market timing effects on corporate capital structures have been specific to ICT firms or the ICT boom episode.

Our results confirm the empirical regularity that historical market-to-book ratios are negatively related to US corporate leverage. However, we also document that these results do not extend to samples of UK and continental firms. The few market timing effects that we find for continental European firms appear to be specific to ICT firms and the ICT boom episode. For UK firms the overall results are insignificant. These results corroborate the 


\section{Discussion of BW's market timing measure}

BW's measure for market timing, the so-called external-finance-weighted average market-tobook ratio $\left(E F W A M B^{B W}\right)$, is defined as follows: ${ }^{1}$

$$
E F W A M B_{t}^{B W}=\sum_{s=1}^{t-1} \frac{e_{s}+d_{s}}{\sum_{r=1}^{t-1} e_{r}+d_{r}} \times M B_{s}
$$

where $e$ and $d$ denote equity and total debt issues, respectively, $M B$ is the market-to-book ratio, and suffix $s$ and $r$ denote time. For a firm observed at time $t, E F W A M B^{B W}$ is the weighted average of a time-series of historical market-to-book ratios, starting with year 1, i.e. the first observation available in the sample, and ending with the market-to-book ratio at $t-1$. The weight for each year is the ratio of external financing in that year to the total external financing raised by the firm in years 1 through $t-1$. Thus, firms that issue a lot of equity when market-to-book ratios are relatively high will tend to have high values of $E F W A M B^{B W}$. BW define equity issues as the change in the book value of share capital and debt issues as the change in the book value of debt.

BW regress leverage on $E F W A M B^{B W}$ plus the usual Rajan and Zingales (1995) set of control variables including unweighted market-to-book, tangibility, profitability and firm size. The unweighted market-to-book ratio controls for 'the cross-sectional variation in the level of market-to-book. What is left for $E F W A M B^{B W}$ is the residual influence of past, within-firm variation in market-to-book' (BW, p. 15; italics in the original). The usual assumptions for the

\footnotetext{
${ }^{1}$ We follow the notation of Hovakimian (2006).
} 
control variables are that larger and more tangible firms are safer debtors and therefore can get more debt, and that the effect of high profitability on leverage is either negative according to the pecking order theory (more funding from retained earnings) or positive according to the trade-off theory (higher tax shield from debt, lower probability of bankruptcy, bigger free cash flow problem).

BW's hypothesis is that if firms systematically time their equity issues to the market and do not consecutively rebalance their capital structures, $E F W A M B^{B W}$ should have a significantly negative effect on leverage. Otherwise, $E F W A M B^{B W}$ would be insignificant. BW test the market timing hypothesis for US firms and indeed find a significantly negative effect of $E F W A M B^{B W}$ on leverage.

At this point we want to emphasize that BW's $E F W A M B^{B W}$ measure of market timing weighs the sum of debt and equity issues by the market-to-book ratio. In the remainder of this section we shall argue that this feature of $E F W A M B^{B W}$ precludes the definition of strong empirical priors concerning its role in capital structure regressions. In particular, we argue that market timing does not necessarily generate a negative effect on leverage in all cases.

1. Substitution between debt and equity. Let us assume that a firm substitutes debt for equity issues and vice versa, depending on the relative costs of equity and debt, while keeping the sum of external finance (equity and debt issues) constant. In that case, a low value for $E F W A M B^{B W}$ would falsely indicate that the firm is not timing the market. In other words, $E F W A M B^{B W}$ is a 'noisy' measure of equity market timing. In this particular case there is also no a priori reason for a statistically significant relationship between $E F W A M B^{B W}$ and leverage. Probably, there would be none. BW's expectation of a negative relationship is based on the assumption that firms issue equity when stock market valuation is high, not on the assumption that firms substitute debt for equity issues when stock market valuation is relatively low.

2. Pecking order. Take a firm with a strong pecking order so that it issues debt instead of equity if retained earnings are insufficient to finance good investment projects. Further, assume that a firm's market-to-book ratio is higher when it has good investment opportunities (Myers, 1977). Thus, $E F W A M B^{B W}$ for a firm may be higher because it issues debt (rather than equity) when stock prices are high. In this setting, a high value for $E F W A M B^{B W}$ would falsely indicate equity market timing. Moreover, in this case one may expect a positive, rather than a negative relationship between $E F W A M B^{B W}$ and leverage.

3. Pecking order variability. The effect of $E F W A M B^{B W}$ on leverage could change in magnitude or even switch sign over time if the pecking order changes over time. Huang and 
Ritter (2009), for example, argue that the pecking order may vary over time and across firms, depending on the relative cost of each type of funding. If the equity risk premium is sufficiently low, firms may even prefer external over internal equity, giving rise to the market timing feature that firms issue equity even when they do not have financing deficits (Frank and Goyal, 2003; Fama and French, 2005). External equity can be costly because of conflicts of interest between management and outside shareholders resulting from the separation of ownership and control (Jensen and Meckling, 1976). If these agency costs are sufficiently high, firms will typically prefer debt over equity in the pecking order. If they are not, managers may prefer external equity over debt when the cost of external equity falls sufficiently (i.e., when stock valuations are sufficiently high).

Summing up:, a negative empirical relationship between $E F W A M B^{B W}$ and capital structure should not be implied a priori, especially for firms that are not characterized by dispersed ownership or that do not operate in financial systems that embed an active market for corporate control such as in the US. Specifically, comparing the role of $E F W A M B^{B W}$ in capital structures on both sides of the Atlantic, we do not expect to find as strong an effect of $E F W A M B^{B W}$ on the capital structure of European firms as is typically found for US firms.

\section{Data}

We use a dataset that contains not only US firms, but also UK and continental European firms. Keeping constant the source of the data, definition of the variables, specification of the capital structure equation and econometric techniques, we can thus assess the stability of the market timing effect in the determination of capital structure across countries and financial systems.

In addition, we distinguish ICT and non-ICT firms so that we may test whether the market timing effects on capital structure were stronger for (or even specific to) ICT firms whose stock prices soared during the dotcom bubble (Figure 1). Firms are denoted ICT-firms if they belong to one of the ICT industries (Appendix A gives the four-digit SIC87 industry classification key used). About one out of four firms in our sample is an ICT firm. Our sample period is 1991-2001 and includes the ICT boom-bust cycle of 1996-2001.

[insert Figure 1 about here] 
Our data are taken from the COMPUSTAT Global data files on publicly traded firms. Following BW, we define equity issues as the change in the book value of share capital and debt issues as the change in the book value of debt. However, we check whether the resulting data on external funding are consistent with the cash flow identity, according to which the external financing deficit ex post should be equal to external funding. ${ }^{2}$ Moreover, we select firms for which there are at least eight consecutive observations on external funding available. This leaves us with an unbalanced panel data set containing 727 firms, among which 230 US firms, 159 UK firms, and 338 continental European firms. ${ }^{3}$

Table 1 gives key financial ratios for the US, the UK and continental Europe. ${ }^{4}$ Within each region, statistics are compared between ICT and non-ICT firms. A few observations catch the eye. First, relative to US firms, long-term debt issues are more important for continental European firms. The average ratio of equity issues to long-term debt issues is nearly 20 for US firms, while it is only about 4 for UK and continental European firms. Consistent with the relative importance of outside equity financing, US leverage ratios are also lowest of all three regions. Second, relative to non-ICT firms, long-term debt issues are about equally important for ICT firms across all regions. At the same time, ICT firms raise about two to three times the amount of external finance on average as non-ICT firms. Cumulative indebtedness is nevertheless lower for ICT firms, the difference relative to nonICT firms being largest in the US sample.

[Table 1 about here]

Table 2 describes the market timing behavior of our sample of firms in terms of the level of the external finance weighted market-to-book ratio. To facilitate comparison between levels, we scale $E F W A M B^{W B}$ by the average level of the market-to-book ratio over each firm's entire sample period, $\overline{M B} .{ }^{5}$ Additionally, we take on board only long-term debt, ltd, rather than total debt, because the former more accurately represents issuance decisions than the latter. ${ }^{6}$ Our market timing measure reads:

\footnotetext{
${ }^{2}$ Specifically, the following cash flow identity should hold: Capital expenditures + investment in working capital - internal cash flow $=$ equity issues + long-term debt issues.

${ }^{3}$ Our data contains firms from Austria, Belgium, Denmark, Finland, France, Germany, Greece, Ireland, Italy, Luxemburg, Netherlands, Norway, Portugal, Spain, Sweden, Switzerland, United Kingdom, and the United States. Despite the broad coverage of countries, the rather limited number of firms for most countries in our sample does not allow for an extensive analysis at the country-level.

${ }^{4}$ The note of this table gives all variable definitions.

${ }^{5}$ We thank Clemens Kool for suggesting this adjustment.

${ }^{6}$ Leverage may also change as a result of short term debt accumulation. We shall in fact focus on debt issues as changes in the book value of long term debt titles only, as short term debt dynamics are strongly driven by inter-
} 


$$
E F W A M B_{t}=\frac{1}{\overline{M B}} \sum_{s=1}^{t-1} \frac{e_{s}+l t d_{s}}{\sum_{r=1}^{t-1} e_{r}+l t d_{r}} \times M B_{s} .
$$

As a result of the scaling, $E F W A M B$ will be 1 if market conditions play no role in the firm's decision to raise external funds. Firms raising external funds specifically in years of aboveaverage market-to-book ratios are characterized by values of EFWAMB exceeding 1 . We note that the value of BW's $E F W A M B^{B W}$ measure, being unscaled, not only reflects market timing behavior but also the average level of market-to-book for a firm. By scaling we allow a direct interpretation of any deviations from 1 of this market timing measure.

Table 2 demonstrates that EFWAMB is typically highest in the US sample and lowest in the continental European sample. Hence, continental European firms are less active market timers than US firms. The exception is the high value for EFWAMB for UK ICT firms, although the difference with US ICT firms is statistically insignificant. Also note that $E F W A M B$ is never larger for ICT firms than for non-ICT firms in statistical terms. In fact, in the US as well as the continental European samples, median EFWAMB is significantly higher for non-ICT firms, suggesting that these firms timed the markets most actively. As Figure 2 demonstrates, though - plotting the development of median EFWAMB over time using fouryear rolling windows - ICT firms have generally become more active market timers in the second half of our sample period.

[Table 2 about here]

[Figure 2 about here]

company (trade) credits, and as such are in large measure induced by normal business operations, and therefore to a large extent are unrelated to market timing or long term capital structure objectives (e.g. Petersen and Rajan, 1997; Bevan and Danbolt, 2002, 2004). 


\section{Results}

We will next explore how the lower market timing activity found for continental European firms compared to US firms feeds into differential effects on capital structures. First, we present leverage regression results for our three regions, followed by some robustness checks. Finally, we give an interpretation of the results.

\subsection{Market timing and capital structure}

Since our main interest is in differences in capital structure determination on both sides of the Atlantic we run capital structure regressions on separate samples of US, UK and continental European firms. To assess differences in market timing effects on the capital structure of ICT and non-ICT firms, we interact $E F W A M B$ with an ICT-dummy variable. We also estimate capital structure equations on four-year moving windows, i.e. the first regression is for the 1993-1996 period and the last regression for the 1998-2001 period. ${ }^{7}$ This strategy enables us to detect changes in the determination of capital structure that may relate to the boom-bust cycle in ICT share prices, without abandoning the time-series dimension of our panel data set. The four-year window is both sufficiently long to allow for a meaningful role for the time series dimension of capital structure determination and sufficiently short to allow for potential changes over time in the determination of capital structure.

We apply generalized least squares (GLS), which unlike OLS allows for the presence of autocorrelation within panels and cross-sectional correlation and heteroskedasticity across panels. As capital structures are typically autocorrelated and heteroskedasticity is a common feature in panels, GLS is especially suitable to our purposes (e.g., Greene, 2003).

The overall estimation results are in Appendix B. Before turning to the role of $E F W A M B$ we give a succinct description of the overall results.

The empirical determinants of corporate capital structure that we use are well-known in the relevant literature (e.g. Harris and Raviv, 1991; Rajan and Zingales, 1995; ShyamSunder and Myers, 1999; Baker and Wurgler, 2002). The same applies to most of the signs of the coefficient estimates that we obtain. Specifically, we find static tradeoff elements in capital structure management in the sense that large firms tend to have higher leverage ratios, while higher interest rates are associated with lower indebtedness. In this regard, the finding that the variable intangibility relates mostly positively to leverage in all three samples is

\footnotetext{
${ }^{7}$ The construction of EFWAMB generates a loss of the first years 1991-1992.
} 
counter-intuitive. In addition to the static trade-off effects, we find pecking order effects in the negative coefficient for profitability. Market-to-book is expected to be negatively related with leverage, based on the underinvestment theory of Myers (1977). According to this theory, firms with high growth opportunities ${ }^{8}$ choose lower leverage to prevent the cost of future underinvestment associated with high leverage. Roughly speaking, leverage in the US sample seems most strongly and negatively connected to market-to-book while this is much less the case in the continental European sample. In the UK sample, the positive connection between UK leverage and market-to-book stands out compared to our findings for the US and continental Europe, although this is a well-documented result in the empirical literature on UK firms' capital structures (e.g. Chittenden et al., 1996; Michaelas et al., 1999; Bevan and Danbolt, 2002). ${ }^{9}$

Our main focus, however, is on $E F W A M B$, capturing the lasting effect of market timing on capital structure. Therefore, Table 3 summarizes the coefficients estimated for $E F W A M B$ for ICT and non-ICT firms in the three regions. These coefficient estimates derive from regression equations that include all the above-mentioned control variables as well as an ICT interaction dummy on EFWAMB (EFWAMB $\times D^{I C T}$, see Appendix Table A2 for the specifics). ${ }^{10}$ Interestingly enough, the estimated coefficients on $E F W A M B$ for non-ICT firms are significantly negative in all time windows for non-ICT firms in the US sample, whereas they are never significantly negative in either the UK or the continental European samples. Hence, while we confirm the negative relationship between EFWAMB and leverage found in other studies for the US (BW; Hovakimian, 2006) for our sample of US firms, this empirical regularity does not seem to extend to our UK and continental European samples. The negative connection between market timing and capital structure therefore stands out as a US phenomenon. ${ }^{11}$

\section{[Table 3 about here]}

\footnotetext{
${ }^{8}$ Penman (1996) demonstrates that under market efficiency the market-to-book ratio is an appropriate indicator of earnings growth, while Cheng (2005) shows that market analysts are fairly efficient in predicting future earnings. This bolsters out confidence in the market-to-book ratio as a proxy for future profitability.

${ }^{9}$ Bevan and Danbolt (2002) note that their significantly positive market-to-book coefficient is driven by trade credit which accounts for more than $62 \%$ of total liabilities of UK firms in their sample. These authors interpret their results as indicating that firms with strong growth potential prefer to finance themselves with interenterprise credit rather than through more formal lines. This is consistent with the predictions of Barclay and Smith (1999) who argue that high growth firms prefer debt with few restrictive covenants in order to maintain financial flexibility.

${ }^{10}$ The $t$-values on the $E F W A M B$ coefficient estimates for ICT firms derive from auxiliary regressions where a non-ICT interaction dummy on $E F W A M B$ is used instead (EFWAMB $x D^{\text {non-ICT }}$ ).

${ }^{11}$ Unreported robustness checks (that are available on request) reveal that this result holds if we lag all explanatory variables by one year. Note that $E F W A M B$ itself by construction only relates to past issuance behaviour (see Equation (2)).
} 


\subsection{Robustness}

Before jumping to conclusions, however, let us first consider a number of potential explanations as to why our results may diverge from those reported by BW. Such explanations potentially also explain why we find such strikingly different results for continental Europe and the UK. To start with, our definition of EFWAMB relates the timing of share and long-term debt issues to changes in total leverage, whereas BW look at the timing of shares and total debt issues and relate this to total leverage. To the extent that the results of continental European market timing are blurred by short-term debt dynamics, it may not be picked up by our $E F W A M B$ variable, resulting in biased coefficient estimates. To check for this, we first synchronize our dependent variable to our definition of EFWAMB and construct leverage as the ratio of long-term debt to assets. Subsequently we check the coefficient estimates on $E F W A M B$, see panel A of Table 4 (as before in Table 3 all output other than the $E F W A M B$ coefficients and absolute $t$-values is suppressed). The resulting EFWAMB coefficients retain their negative signs and statistical significance in all but one window in the US sample. In the UK sample we still find no significant market timing effects. In our continental European sample, however, the $E F W A M B$ coefficients are now significantly positive. This is a remarkable result, which we will examine further in Section 4.3.

[Table 4 about here]

But first, as a second robustness check, we synchronize $E F W A M B$ to the definition of BW, see Equation (1). The resulting EFWAMB coefficient estimates are in panel B of Table 4. The $E F W A M B$ coefficients retain their negative signs and significance in the US regressions, while little or no statistically significant connection is detected in either the UK or the continental European sample.

Summing up, we confirm the empirical regularity that US capital structures associate negatively with $E F W A M B$, consistent with the market timing theory. We find robust evidence, however, that this result does not extend to UK and continental European samples.

\subsection{European firms issue more debt when stock prices are high}


We now turn to the significantly positive association between EFWAMB and long-term debt ratios that was found for continental European firms. As argued in Section 2, such a positive association may result when firms issue long-term debt rather than equity when stock prices are high. To further examine this hypothesis, we define two alternative market timing measures, the external equity weighted average market-to-book (EEWAMB) and the long-term debt weighted average market-to-book ratios (DWAMB), respectively:

$$
\begin{aligned}
& \operatorname{EEWAMB}_{t}=\frac{1}{\overline{M B}} \sum_{s=1}^{t-1} \frac{e_{s}}{\sum_{r=1}^{t-1} e_{r}} \times M B_{s} \\
& D W A M B_{t}=\frac{1}{\overline{M B}} \sum_{s=1}^{t-1} \frac{l t d_{s}}{\sum_{r=1}^{t-1} l t d_{r}} \times M B_{s}
\end{aligned}
$$

To identify potentially separate effects of the timing of equity and long-term debt issues on leverage, panel $\mathrm{C}$ of Table 4 presents regression results for these two measures. The results for the continental European sample show that the timing of equity issues has little impact on capital structures, whereas the timing of long-term debt issues is associated with higher leverage ratios. This leads to the conclusion that the non-existence of a significantly negative relationship between $E F W A M B$ and leverage for European firms is due to the fact that, apparently, these firms issue debt rather than equity when stock prices are high.

For the UK sample the results remain insignificant, while for the US sample the timing of equity issues $(E E W A M B)$ retains its negative connection with leverage, though not always significantly, while the timing of long-term debt issues is insignificant, except in the beginning of the sample.

\subsection{Pecking order variability over time}

Our main contribution in this paper is to give evidence of the insignificance of market timing effects on capital structures in Europe, in contrast to the existing evidence for the US. An extensive analysis into the reasons for this difference between the regions lies beyond the scope of this paper and is thus left for future research. However, we allow ourselves to make some suggestions as to the possible directions into which such further search might be conducted. For this reason we explore some recent literature on the subject.

Högfeldt and Oborenko (2005) argue that European firms' capital structures are less sensitive to market timing compared to their US counterparts', because the former have a 
stronger preference for debt over equity when external financing is needed. They link this stronger pecking order in Europe to the rather concentrated ownership of continental European firms and the relatively strong separation of ownership and control, both of which would generate a relatively large wedge between the costs of debt and external equity.

There are several papers that attempt reconciling the pecking order theory with the market timing theory by assuming that adverse selection costs are time-varying. Early contributions by, for example, Korajczyk et al. (1992) and Choe et al. (1989) emphasize that firms attempt to issue equity specifically when problems related to asymmetric information are expected to be relatively unimportant. Dittmar and Thakor (2007) argue that the likelihood of disagreement between shareholders and management concerning project choice is lower when stock prices are high, and that managers issue equity when they believe that investors' views about project payoffs are aligned with theirs. Within this setting, we may expect the pecking order to vary with stock price valuation. Huang and Ritter (2009) assume that, under pecking order financing, in times of normal stock price valuations debt issues are preferred over external equity issues. In their view external equity may by exception be preferred over debt when stock price valuations are relatively high.

In connection to our analysis at hand, the key idea behind all this is that reversals of the pecking order may be less likely to occur in Europe than in the US, as in Europe the cost differential between external equity and debt may be relatively large. It could be precisely for this reason that high stock prices would induce US firms to prefer external equity issues over debt issues - driving the negative relationship between EFWAMB and leverage - whereas European firms would continue to prefer debt over external equity issues and for that reason exhibit an insignificant connection between $E F W A M B$ and leverage.

Further research of this hypothesis would preferably require extensive data on cost differentials between debt and external equity (issues) and/or on ownership structures of companies. As these data are notoriously hard to come by we cannot in the present paper indulge in an in-depth analysis of this kind. What we can do is offer circumstantial evidence which may fall some way short of being solid evidence in favor of such a hypothesis, but at least be consistent with it. In particular, we exploit the heterogeneity between firms within $a$ region to test whether capital structures of firms (temporarily) experiencing relatively high stock price valuations are more susceptible to pick up market timing effects than firms without such stock market events. In our samples, we specifically employ the heterogeneity between ICT firms and non-ICT firms. Since ICT firms have seen such tremendous swings in share prices over our sample period everywhere, we may expect to see some of this varying 
ordering of the pecking order in play, even in the European sample. Thus ICT firms may have had a stronger appetite for outside equity financing relative to debt for some years, specifically during the ICT stock price boom. If this is the case, the coefficient on EFWAMB in leverage regressions should turn (more) negative for ICT firms in those ICT boom years and revert to pre-boom levels thereafter.

Turning back to the EFWAMB coefficients for ICT firms presented in Table 3, such a pattern is indeed apparent. For US ICT firms, the $E F W A M B$ coefficients turn significantly negative in the 1996-1999 window and reaches a trough in the 1997-2000 window, which coincides with the peak in ICT share prices. Subsequently, the 1998-2002 EFWAMB coefficient drops towards pre-boom levels, turning insignificant as before. Similar patterns in the development of ICT firms' EFWAMB coefficients can be distinguished for the UK and continental European samples, though in statistical terms it is only visible in continental Europe. For the continental European sample, EFWAMB is found to be significantly negative only for ICT firms and then only at the peak of the ICT boom episode (1997-2000).

These findings are important for two reasons. Firstly, they suggest that market timing has been more important for those firms that experienced episodes of (extremely) high share price valuation. For these firms and in those episodes, market timing effects on capital structure are discernible even in continental Europe. This warrants further research on the precise factors that drive market timing and its effects on capital structure along the lines sketched above. Secondly, they reiterate that market timing effects on corporate capital structure in continental Europe are limited and short-lived. In our sample they appear to be specific to ICT firms and the ICT stock market boom.

\section{Conclusion}

This paper provides comparative international evidence on the correlation between market timing and corporate capital structures using panel data for US, UK, and continental European firms. We document that the US empirical regularity, that market timing and corporate leverage correlates negatively, does not extend to samples of UK and continental European firms. The few market timing effects on European firms' capital structures that we find appear to be specific to ICT firms and the ICT boom episode. We demonstrate that continental European firms tend to raise leverage ratios when stock prices are high by timing long-termdebt issues, thus apparently sticking more strongly to a pecking order where debt is preferred over external equity. 


\section{Acknowledgements}

We gratefully acknowledge useful comments of an anonymous referee, as well as of Jan Marc Berk, Jaap Bos, Tijs de Bie, Jakob de Haan, Peter van Els, Jim Kolari, Clemens Kool, participants of the 60th International Atlantic Economic Conference (New York), the 34th Eurobanking Conference (Dubrovnik), Erasmus Finance Day 2007 (Rotterdam), and seminar participants at ABN-Amrobank, Free University, De Nederlandsche Bank and Rabobank. 


\section{References}

Alti, A. (2006), How persistent is the impact of market timing on capital structure? Journal of Finance, 61, 1681-1710.

Baker, M. and Wurgler, J. (2002), Market timing and capital structure, Journal of Finance, 57, 1-32.

Barclay, M.J. and Smith, C.W. (1999), The capital structure puzzle: Another look at the evidence, Journal of Applied Corporate Finance, 12, 8-20.

Bevan, A.A. and Danbolt, J. (2002), Capital structure and its determinants in the UK: A decompositional analysis, Applied Financial Economics, 12, 159-170.

Bevan, A.A. and Danbolt, J. (2004), Testing for inconsistencies in the estimation of UK capital structure determinants, Applied Financial Economics, 14, 55-66.

Bruinshoofd, W.A. and De Haan, L. (2011), Is the negative relation between leverage and historical market-to-book specific to US and Information and Communication Technology firms?, International Review of Finance, forthcoming.

Cheng, Q. (2005), The role of analysts' forecasts in accounting-based valuation: A critical evaluation, Review of Accounting Studies, 10, 5-31.

Chittenden, F., Hall, G. and Hutchinson, P. (1996), Small firm growth, access to capital markets and financial structure: Review of issues and an empirical investigation, Small Business Economics, 8, 59-67.

Choe, H., Masulis, R.W. and Nanda, V.K. (1992), Common stock offerings across the business cycle: theory and evidence, Journal of Empirical Finance, 1, 3-31.

De Bie, T. and De Haan, L. (2007), Market timing and capital structure: evidence for Dutch firms, De Economist, 155(2), 183-206

Dittmar, A. and Thakor, A. (2007), Why do firms issue equity?, Journal of Finance 62, 1-54.

Fama, E.F. and French, K.R. (2005), Financing decisions: who issues stock?, Journal of Financial Economics, 76, 549-582.

Frank, M.Z. and Goyal, V.K. (2003), Testing the pecking order theory of capital structure, Journal of Financial Economics, 67, 217-248.

Greene, W.H. (2003), Econometric Analysis, 5th ed., Upper Saddle River, New Jersey: Prentice Hall.

Harris, M., and Raviv, A. (1991), The theory of capital structure, Journal of Finance, 46, 297355. 
Hegge, M. (2006), Is market timing less interesting for Dutch and Belgian firms?, Working paper, University of Amsterdam.

Högfeldt, P. and Oborenko, A. (2005), Does market timing or enhanced pecking order determine capital structure?, European Corporate Governance Institute Research Paper no. 72 .

Hovakimian, A. (2006), Are observed capital structures determined by equity market timing?, Journal of Financial and Quantitative Analysis, 41, 221-243.

Huang, R. and Ritter, J.R. (2009), Testing the market timing theory of capital structure, Journal of Financial and Quantitative Analysis, 44, 237-271.

Jensen M.C. and Meckling, W.H. (1976), Theory of the firm: managerial behavior, agency costs and ownership structure, Journal of Financial Economics, 3, 305-360.

Kayhan, A. and Titman, S. (2007), Firms' histories and their capital structures, Journal of Financial Economics, 83, 1-32.

Korajczyk, R.A. Lucas, D.J. and McDonald, R.L. (1992), Equity issues with time-varying asymmetric information, Journal of Financial and Quantitative Analysis, 27(3), $397-$ 417.

Mahajan, A. and Tartaroglu, S. (2008), Equity market timing and capital structure: International evidence, Journal of Banking and Finance, 32, 754-766.

Leary, M.T. and Roberts, M.R. (2005), Do firms rebalance their capital structures?, Journal of Finance, 60, 2575-2619.

Mendes, E., Kayo, E. and Basso, L.C. (2005), Capital structure and windows of opportunities: Tests in the Brazilian market, Working paper, Mackenzie Presbiterian University, Brazil.

Michaelas, N., Chittenden, F. and Poutziouris, P. (1999), Financial policy and capital structure choice in UK SMEs: Empirical evidence from company panel data, Small Business Economics, 12, 113-130.

Myers, S. C. (1977), Determinants of corporate borrowing, Journal of Financial Economics, $5,147-175$.

Rajan, R.G. and Zingalez, L. (1995), What do we know about capital structure? Some evidence from international data, Journal of Finance, 50, 1421-1460.

Penman, S. H. (1996), The articulation of price-earnings ratios and market-to-book ratios and the evaluation of growth, Journal of Accounting Research, 34, 235-259.

Petersen, M.A. and Rajan, R.G. (1997), Trade credit: theories and evidence, Review of Financial Studies, 10, 661-691. 
Shyam-Sunder, L. and Myers, S.C. (1999), Testing static tradeoff against pecking order models of capital structure, Journal of Financial Economics, 51, 219-244.

Welch, I. (2004), Capital structure and stock returns, Journal of Political Economy, 112, 106131. 
Table 1

Descriptive statistics 1991-2001

\begin{tabular}{|c|c|c|c|}
\hline \multirow[t]{2}{*}{ Variable } & \multicolumn{2}{|c|}{ Median values } & \multirow{2}{*}{$\begin{array}{c}\text { Difference } \\
\text { ICT minus } \\
\text { non-ICT }\end{array}$} \\
\hline & Non-ICT & ICT & \\
\hline \multicolumn{4}{|l|}{ United States } \\
\hline Leverage & 0.546 & 0.380 & $-0.166^{* *}$ \\
\hline Profitability & 0.075 & 0.066 & $-0.009^{* *}$ \\
\hline Size & 5.885 & 4.617 & $-1.268^{* *}$ \\
\hline Interest rate & 0.082 & 0.082 & 0.000 \\
\hline Market-to-book & 1.399 & 1.919 & $0.520^{* *}$ \\
\hline Intangibility & 0.052 & 0.016 & $-0.036^{* *}$ \\
\hline Net debt issues ${ }^{a}$ & 0.004 & 0.012 & 0.008 \\
\hline Net equity issues ${ }^{a}$ & 0.073 & 0.235 & $0.162^{* *}$ \\
\hline \multicolumn{4}{|l|}{ United Kingdom } \\
\hline Leverage & 0.538 & 0.483 & $-0.055^{* *}$ \\
\hline Profitability & 0.057 & 0.066 & $0.009^{* *}$ \\
\hline Size & 4.653 & 3.774 & $0.879^{* *}$ \\
\hline Interest rate & 0.085 & 0.085 & 0.000 \\
\hline Market-to-book & 1.378 & 2.057 & $0.679^{\text {** }}$ \\
\hline Intangibility & 0.000 & 0.001 & $0.001^{* *}$ \\
\hline Net debt issues ${ }^{a}$ & 0.010 & 0.022 & 0.012 \\
\hline Net equity issues ${ }^{a}$ & 0.039 & 0.134 & $0.095^{* *}$ \\
\hline \multicolumn{4}{|l|}{ Continental Europe } \\
\hline Leverage & 0.639 & 0.560 & $-0.079^{* *}$ \\
\hline Profitability & 0.066 & 0.063 & -0.003 \\
\hline Size & 5.857 & 4.647 & $-1.210^{* *}$ \\
\hline Interest rate & 0.079 & 0.082 & 0.003 \\
\hline Market-to-book & 1.183 & 1.617 & $0.434^{* *}$ \\
\hline Intangibility & 0.019 & 0.052 & $0.033^{* *}$ \\
\hline Net debt issues ${ }^{\text {a }}$ & 0.009 & 0.018 & 0.009 \\
\hline Net equity issues ${ }^{a}$ & 0.034 & 0.070 & $0.036^{* *}$ \\
\hline
\end{tabular}

Note: Variable definitions are the following. Leverage: total debt as a fraction of total assets. Profitability: earnings after interest, taxes and dividends, but before depreciation and amortization as a fraction of total assets. Size: the logarithm of total assets in 2000 prices. Interest rate: total interest expense as a fraction of total debt. Market-to-book: the market value of the firm relative to the book value of assets; calculated as book value of debt plus market value of equity divided by book value of total assets. Intangibility: the amount of intangible assets relative to total assets. Net debt issues: the change in the book value of long term debt as a fraction of total assets. Net equity issues: the change in the book value of stock capital as a fraction of total assets.

Statistical significance of the difference in medians at the 5 or 1 percent level is indicated by $*$ and ${ }^{* *}$, respectively, using the continuity corrected Pearson $\chi^{2}(1)$ test.

a) Means are reported rather than median values as median values are zero. Statistical significance of the difference in means is calculated using the $t$-test. 


\section{Table 2}

\section{EFWAMB by sector}

\begin{tabular}{|c|c|c|c|c|}
\hline & All firms & non-ICT firms & ICT firms & $\begin{array}{c}\text { Difference } \\
\text { non-ICT vs. } \\
\text { ICT } \\
\end{array}$ \\
\hline United States & 1.031 & 1.039 & 1.008 & $0.031^{* *}$ \\
\hline $\begin{array}{l}\text { United Kingdom } \\
\text { (difference vs. United States) }\end{array}$ & $\begin{array}{c}1.015 \\
\left(-0.016^{*}\right)\end{array}$ & $\begin{array}{c}1.014 \\
\left(-0.025^{* *}\right)\end{array}$ & $\begin{array}{c}1.056 \\
(0.048)\end{array}$ & 0.042 \\
\hline $\begin{array}{l}\text { Continental Europe } \\
\text { (difference vs. United States) } \\
\text { (difference vs. United Kingdom) }\end{array}$ & $\begin{array}{c}1.003 \\
\left(-0.028^{* *}\right) \\
\left(-0.012^{*}\right)\end{array}$ & $\begin{array}{c}1.005 \\
\left(-0.034^{* *}\right) \\
(-0.009)\end{array}$ & $\begin{array}{c}0.972 \\
\left(-0.036^{* *}\right) \\
\left(-0.084^{* *}\right)\end{array}$ & $0.033^{*}$ \\
\hline
\end{tabular}


Table 3

Historical market-to-book effects in capital structure regressions

\begin{tabular}{lccccccc}
\hline & $1993-$ & $1994-$ & $1995-$ & $1996-$ & $1997-$ & $1998-$ & Full \\
& 1996 & 1997 & 1998 & 1999 & 2000 & 2001 & sample \\
\hline United States & & & & & & & \\
Non-ICT firms & $-0.085^{* *}$ & $-0.111^{* *}$ & $-0.106^{* *}$ & $-0.118^{* *}$ & $-0.086^{* *}$ & $-0.075^{* *}$ & $-0.087^{* *}$ \\
& $(5.5)$ & $(10.7)$ & $(8.0)$ & $(6.8)$ & $(4.9)$ & $(3.7)$ & $(6.3)$ \\
ICT firms & 0.006 & 0.006 & -0.016 & $-0.059^{*}$ & $-0.080^{* *}$ & -0.018 & -0.019 \\
& $(0.2)$ & $(0.5)$ & $(0.6)$ & $(2.5)$ & $(4.2)$ & $(0.5)$ & $(0.8)$ \\
United Kingdom & & & & & & & \\
Non-ICT firms & 0.028 & $0.058^{* *}$ & 0.025 & 0.015 & -0.001 & -0.003 & 0.020 \\
& $(1.8) *$ & $(4.1)$ & $(1.1)$ & $(0.7)$ & $(0.0)$ & $(0.1)$ & $(1.1)$ \\
ICT firms & $-0.123^{*}$ & 0.051 & 0.018 & -0.105 & -0.097 & -0.053 & -0.036 \\
& $(2.2)$ & $(0.5)$ & $(0.3)$ & $(1.6)$ & $(1.5)$ & $(0.9)$ & $(0.7)$ \\
Continental Europe & & & & & & & \\
Non-ICT firms & 0.006 & 0.003 & -0.006 & 0.016 & 0.023 & 0.003 & 0.002 \\
& $(0.5)$ & $(0.3)$ & $(0.5)$ & $(1.2)$ & $(1.8)$ & $(0.2)$ & $(0.2)$ \\
ICT firms & -0.072 & 0.003 & -0.045 & -0.047 & $-0.094^{*}$ & -0.025 & $-0.077^{*}$ \\
& $(1.9)$ & $(0.1)$ & $(0.9)$ & $(1.0)$ & $(2.0)$ & $(0.6)$ & $(2.3)$ \\
\hline
\end{tabular}

Note: The dependent variable is leverage. Appendix A specifies the four-digit SIC codes that we classify as ICT industries. Additional control variables as per Appendix B are included, but only the coefficients on externalfinance-weighted market-to-book (EFWAMB) are reported. Appendix B presents the regression results in full. Presented results derive from cross-sectional time-series FGLS regressions, allowing for heteroskedastic panels and a common autoregressive coefficient for all panels. * and $* *$ denote statistical significance at the $5 \%$ and $1 \%$ level, respectively. 


\section{Table 4}

Robustness: historical market-to-book effects in various specifications

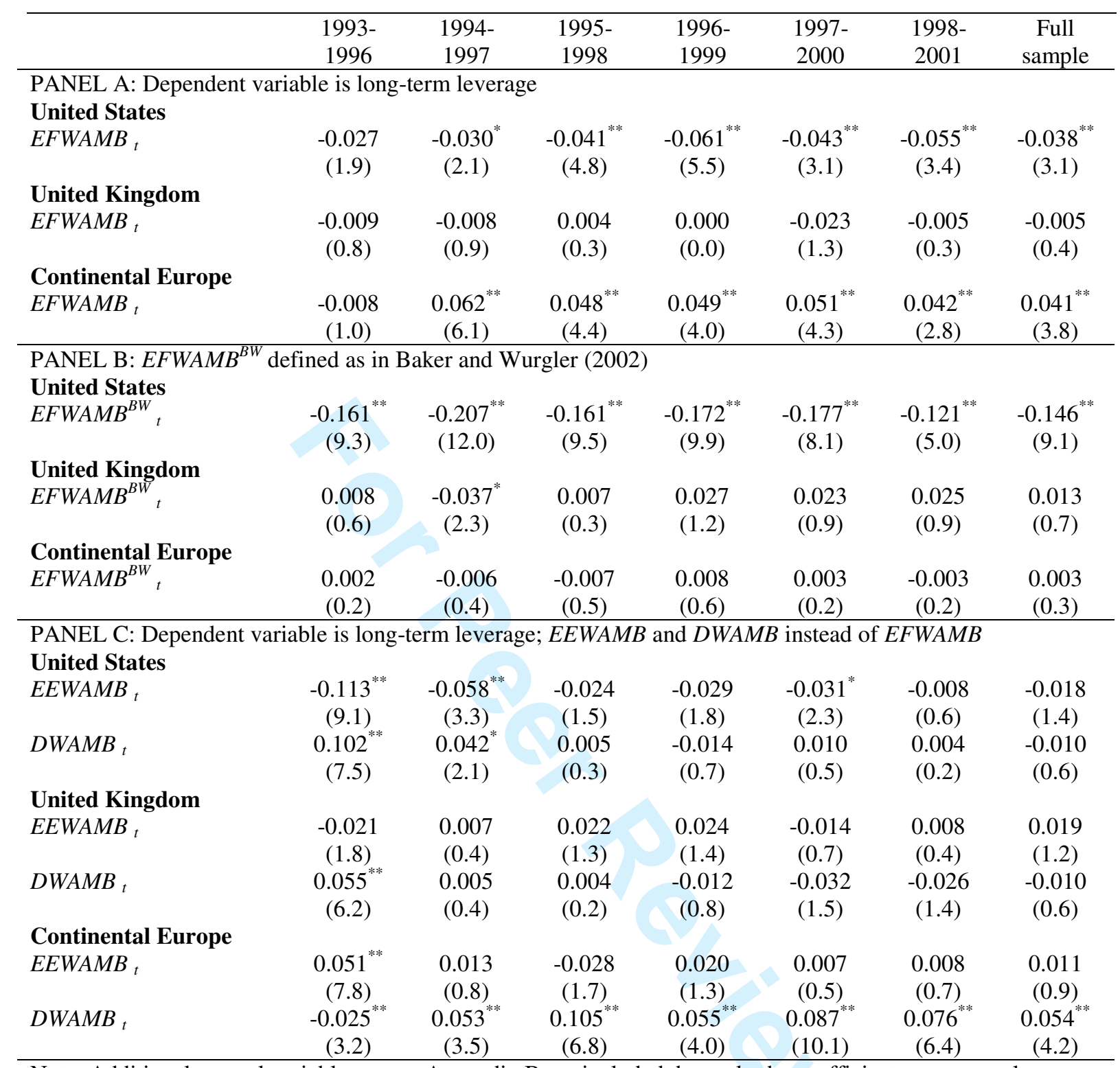

Note: Additional control variables as per Appendix B are included, but only the coefficients on externalfinance-weighted market-to-book are reported. Presented results derive from cross-sectional time-series FGLS regressions, allowing for heteroskedastic panels and a common autoregressive coefficient for all panels. * and ** denote statistical significance at the $5 \%$ and $1 \%$ level, respectively. 
Fig. 1 - Stock price index $(1995=100)$

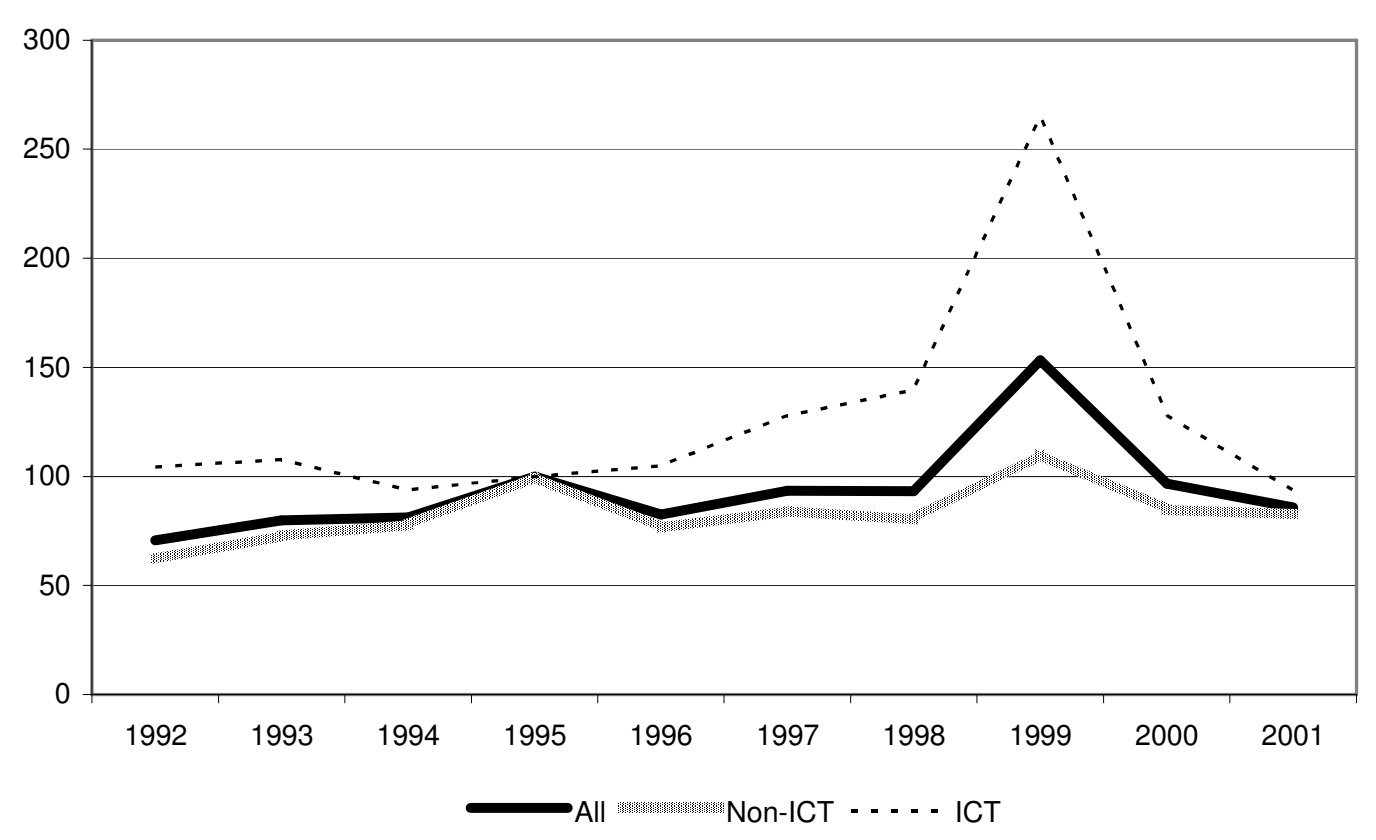

Source: Compustat, authors' calculations. 
Figure 2

Median EFWAMB by region and period

United States

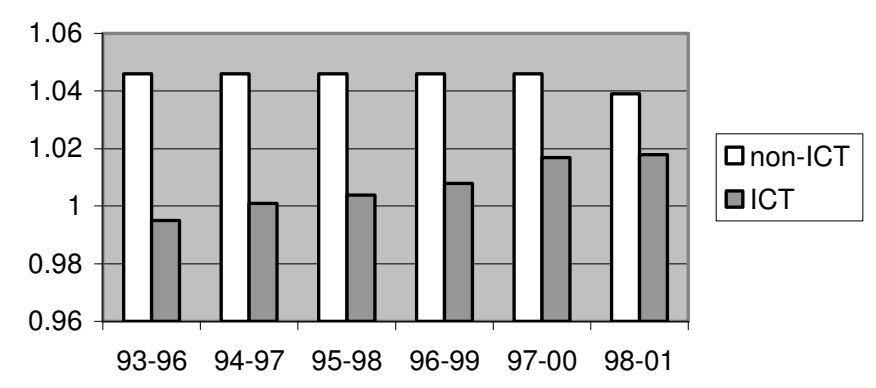

United Kingdom

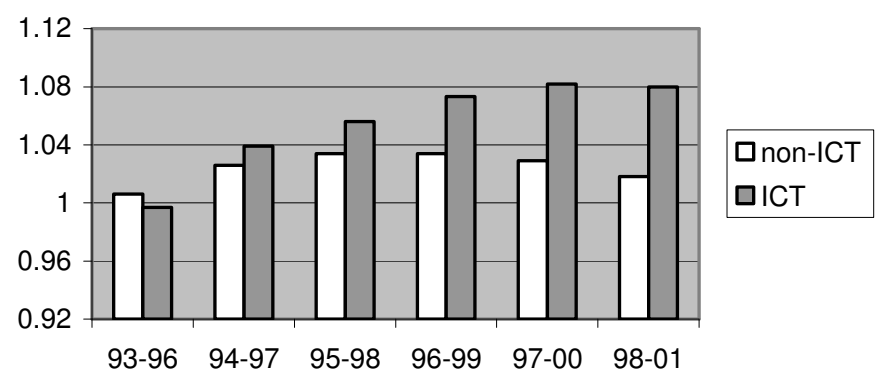

Continental Europe

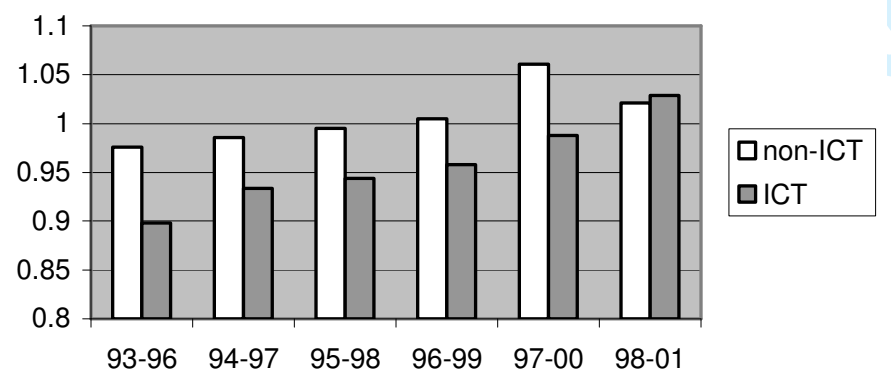




\section{APPENDIX A}

\section{ICT industries (SIC 1987 codes)}

\begin{tabular}{|c|c|}
\hline $\begin{array}{l}\text { SIC } \\
\text { code }\end{array}$ & Sector description \\
\hline 3571 & Electronic Computers \\
\hline 3572 & Computer Storage Devices \\
\hline 3575 & Computer Terminals \\
\hline 3576 & Computer Communications Equipment \\
\hline 3577 & Computer Peripheral Equipment, NEC \\
\hline 3613 & Switchgear and Switchboard Apparatus \\
\hline 3629 & Electrical Industrial Apparatus, NEC \\
\hline 3651 & Household Audio and Video Equipment \\
\hline 3652 & Phonograph Records and Prerecorded Audio Tapes and Disks \\
\hline 3661 & Telephone and Telegraph Apparatus \\
\hline 3663 & Radio and Television Broadcasting and Communications Equipment \\
\hline 3669 & Communications Equipment, NEC \\
\hline 3671 & Electron Tubes \\
\hline 3672 & Printed Circuit Boards \\
\hline 3674 & Semiconductors and Related Devices \\
\hline 3675 & Electronic Capacitors \\
\hline 3676 & Electronic Resistors \\
\hline 3677 & Electronic Coils, Transformers, and Other Inductors \\
\hline 3678 & Electronic Connectors \\
\hline 3679 & Electronic Components, NEC \\
\hline 3695 & Magnetic and Optical Recording Media \\
\hline 3699 & Electrical Machinery, Equipment, and Supplies, NEC \\
\hline 3812 & Search, Detection, Navigation, Guidance, and (Aero)nautical Systems and Instruments \\
\hline 3823 & $\begin{array}{l}\text { Industrial Instruments for Measurement, Display, and Control of Process Variables; and } \\
\text { Related }\end{array}$ \\
\hline 3824 & Totalizing Fluid Meters and Counting Devices \\
\hline 3825 & Instruments for Measuring and Testing of Electricity and Electrical Signals \\
\hline 3826 & Laboratory Analytical Instruments \\
\hline 3827 & Optical Instruments and Lenses \\
\hline 3829 & Measuring and Controlling Devices, NEC \\
\hline 3861 & Photographic Equipment and Supplies \\
\hline 3873 & Watches, Clocks, Clockwork Operated Devices and Parts \\
\hline 4812 & Radiotelephone Communications \\
\hline 4813 & Telephone Communications, Except Radiotelephone \\
\hline 4822 & Telegraph and Other Message Communications \\
\hline 4832 & Radio Broadcasting Stations \\
\hline 4833 & Television Broadcasting Stations \\
\hline 4841 & Cable and Other Pay Television Services \\
\hline 4899 & Communications Services, NEC \\
\hline 5045 & Computers and Computer Peripheral Equipment and Software \\
\hline 5063 & Electrical Apparatus and Equipment Wiring Supplies, and Construction Materials \\
\hline 5064 & Electrical Appliances, Television and Radio Sets \\
\hline 5065 & Electronic Parts and Equipment, NEC \\
\hline 5072 & Hardware \\
\hline 5731 & Radio, Television, and Consumer Electronics Stores \\
\hline 5734 & Computer and Computer Software Stores \\
\hline 7371 & Computer Programming Services \\
\hline 7372 & Prepackaged Software \\
\hline 7373 & Computer Integrated Systems Design \\
\hline 7374 & Computer Processing and Data Preparation and Processing Services \\
\hline 7375 & Information Retrieval Services \\
\hline 7376 & Computer Facilities Management Services \\
\hline 7377 & Computer Rental and Leasing \\
\hline 7378 & Computer Maintenance and Repair \\
\hline 7379 & Computer Related Services, NEC \\
\hline
\end{tabular}


APPENDIX B - Capital structure regression results

\begin{tabular}{|c|c|c|c|c|c|c|c|}
\hline & $\begin{array}{l}1993- \\
1996\end{array}$ & $\begin{array}{l}1994- \\
1997\end{array}$ & $\begin{array}{l}1995- \\
1998\end{array}$ & $\begin{array}{l}1996- \\
1999\end{array}$ & $\begin{array}{l}1997- \\
2000\end{array}$ & $\begin{array}{l}1998- \\
2001\end{array}$ & $\begin{array}{c}\text { Full } \\
\text { sample }\end{array}$ \\
\hline \multicolumn{8}{|l|}{ United States } \\
\hline Profitability ${ }_{t}$ & $\begin{array}{l}-0.545^{* *} \\
(10.4)\end{array}$ & $\begin{array}{l}-0.784^{* *} \\
(14.3)\end{array}$ & $\begin{array}{l}-0.814^{* *} \\
(15.2)\end{array}$ & $\begin{array}{l}-0.652^{* *} \\
(13.9)\end{array}$ & $\begin{array}{l}-0.573^{* *} \\
(13.3)\end{array}$ & $\begin{array}{l}-0.564^{* *} \\
(13.1)\end{array}$ & $\begin{array}{c}-0.557^{* *} \\
(15.8)\end{array}$ \\
\hline Size $_{t}$ & $\begin{array}{l}0.036^{* *} \\
(16.8)\end{array}$ & $\begin{array}{l}0.035^{* *} \\
(20.2)\end{array}$ & $\begin{array}{l}0.038^{* *} \\
(21.4)\end{array}$ & $\begin{array}{l}0.035^{* *} \\
(17.8)\end{array}$ & $\begin{array}{l}0.034^{* *} \\
(17.2)\end{array}$ & $\begin{array}{l}0.035^{* * *} \\
(14.7)\end{array}$ & $\begin{array}{c}0.039^{* * *} \\
(21.1)\end{array}$ \\
\hline Interest rate $_{\mathrm{t}}$ & $\begin{array}{c}-0.293^{* * *} \\
(6.6)\end{array}$ & $\begin{array}{c}-0.252^{* * *} \\
(6.0)\end{array}$ & $\begin{array}{c}-0.308^{* * *} \\
(7.0)\end{array}$ & $\begin{array}{c}-0.274^{* * *} \\
(6.9)\end{array}$ & $\begin{array}{c}-0.234^{* *} \\
(6.4)\end{array}$ & $\begin{array}{l}-0.375^{* * *} \\
(9.9)\end{array}$ & $\begin{array}{c}-0.298^{* * *} \\
(10.3)\end{array}$ \\
\hline Market-to-book $_{\mathrm{t}}$ & $\begin{array}{l}-0.019^{* *} \\
(4.4)\end{array}$ & $\begin{array}{l}-0.012^{* *} \\
(4.0)\end{array}$ & $\begin{array}{l}-0.010^{* * *} \\
(4.3)\end{array}$ & $\begin{array}{c}-0.009^{*} \\
(2.5)\end{array}$ & $\begin{array}{c}-0.004 \\
(1.7)\end{array}$ & $\begin{array}{c}-0.008^{*} \\
(2.4)\end{array}$ & $\begin{array}{c}-0.009^{* *} \\
(3.9)\end{array}$ \\
\hline Intangibility ${ }_{t}$ & $\begin{array}{c}-0.004 \\
(0.1)\end{array}$ & $\begin{array}{c}0.055^{*} \\
(2.5)\end{array}$ & $\begin{array}{c}0.144^{* * *} \\
(4.9)\end{array}$ & $\begin{array}{c}0.241^{* * *} \\
(10.6)\end{array}$ & $\begin{array}{l}0.244^{* * *} \\
(10.3)\end{array}$ & $\begin{array}{c}0.200^{* *} \\
(7.3)\end{array}$ & $\begin{array}{c}0.120^{* * *} \\
(4.6)\end{array}$ \\
\hline EFWAMB $_{t}$ & $\begin{array}{l}-0.085^{* *} \\
(5.5)\end{array}$ & $\begin{array}{l}-0.111^{* *} \\
(10.7)\end{array}$ & $\begin{array}{l}-0.106^{* * *} \\
(8.0)\end{array}$ & $\begin{array}{c}-0.118^{* * *} \\
(6.8)\end{array}$ & $\begin{array}{c}-0.086^{* *} \\
(4.9)\end{array}$ & $\begin{array}{c}-0.075^{* *} \\
(3.7)\end{array}$ & $\begin{array}{c}-0.087^{* *} \\
(6.3)\end{array}$ \\
\hline EFWAMB $_{\mathrm{t}} \times \mathrm{D}^{\mathrm{ICT}}$ & $\begin{array}{c}0.091^{* * *} \\
(3.0)\end{array}$ & $\begin{array}{l}0.117^{* * *} \\
(7.2)\end{array}$ & $\begin{array}{c}0.090^{* *} \\
(2.9)\end{array}$ & $\begin{array}{c}0.059^{*} \\
(2.0)\end{array}$ & $\begin{array}{c}0.005 \\
(0.2)\end{array}$ & $\begin{array}{l}0.058 \\
(1.4)\end{array}$ & $\begin{array}{c}0.068^{*} \\
(2.5)\end{array}$ \\
\hline $\mathrm{D}^{\mathrm{ICT}}$ & $\begin{array}{c}-0.111^{* *} \\
(3.0)\end{array}$ & $\begin{array}{c}-0.136^{* *} \\
(5.8)\end{array}$ & $\begin{array}{c}-0.119^{* * *} \\
(3.2)\end{array}$ & $\begin{array}{c}-0.078^{*} \\
(2.4)\end{array}$ & $\begin{array}{c}-0.020 \\
(0.7)\end{array}$ & $\begin{array}{c}-0.091^{*} \\
(2.0)\end{array}$ & $\begin{array}{c}-0.096^{* * *} \\
(3.0)\end{array}$ \\
\hline \# observations & 604 & 766 & 853 & 885 & 894 & 852 & 1731 \\
\hline \# firms & 195 & 215 & 228 & 230 & 232 & 229 & 241 \\
\hline Pseudo $\mathrm{R}^{2}$ & 0.357 & 0.381 & 0.462 & 0.433 & 0.375 & 0.420 & 0.397 \\
\hline Wald test & $587.1^{* *}$ & $1190.0^{* * *}$ & $1256.2^{* *}$ & $1296.4^{* *}$ & $1130.2^{* *}$ & $760.2^{* *}$ & $1270.7^{* *}$ \\
\hline $\begin{array}{l}\text { Common AR(1) } \\
\text { coefficient }\end{array}$ & 0.73 & 0.44 & 0.69 & 0.71 & 0.78 & 0.77 & 0.75 \\
\hline \multicolumn{8}{|l|}{ United Kingdom } \\
\hline Profitability ${ }_{t}$ & $\begin{array}{c}-0.340^{* *} \\
(3.3)\end{array}$ & $\begin{array}{c}-0.347^{* *} \\
(6.2)\end{array}$ & $\begin{array}{c}-0.415^{* * *} \\
(7.2)\end{array}$ & $\begin{array}{c}-0.392^{* *} \\
(6.2)\end{array}$ & $\begin{array}{c}-0.338^{* *} \\
(5.0)\end{array}$ & $\begin{array}{c}-0.415^{* *} \\
(6.2)\end{array}$ & $\begin{array}{c}-0.385^{* *} \\
(7.3)\end{array}$ \\
\hline Size $_{t}$ & $\begin{array}{c}0.005 \\
(1.6)\end{array}$ & $\begin{array}{l}0.021^{* * *} \\
(3.9)\end{array}$ & $\begin{array}{c}0.009^{* *} \\
(3.5)\end{array}$ & $\begin{array}{c}0.010^{* *} \\
(4.1)\end{array}$ & $\begin{array}{c}0.015^{* *} \\
(6.5)\end{array}$ & $\begin{array}{l}0.018^{* *} \\
(7.0)\end{array}$ & $\begin{array}{l}0.020^{* *} \\
(7.6)\end{array}$ \\
\hline Interest rate $_{t}$ & $\begin{array}{c}-0.314^{* *} \\
(4.3)\end{array}$ & $\begin{array}{c}-0.230^{* * *} \\
(7.2)\end{array}$ & $\begin{array}{c}-0.205^{* * *} \\
(5.1)\end{array}$ & $\begin{array}{l}-0.120^{* * *} \\
(3.4)\end{array}$ & $\begin{array}{c}-0.120^{* *} \\
(4.0)\end{array}$ & $\begin{array}{c}-0.110^{* * *} \\
(4.4)\end{array}$ & $\begin{array}{c}-0.132^{* *} \\
(5.7)\end{array}$ \\
\hline Market-to-book $_{\mathrm{t}}$ & $\begin{array}{c}0.026^{* *} \\
(3.4)\end{array}$ & $\begin{array}{c}0.021^{* *} \\
(4.8)\end{array}$ & $\begin{array}{c}0.028^{* * *} \\
(5.5)\end{array}$ & $\begin{array}{c}0.023^{* *} \\
(4.9)\end{array}$ & $\begin{array}{c}0.012^{*} \\
(2.5)\end{array}$ & $\begin{array}{c}0.015^{* *} \\
(3.0)\end{array}$ & $\begin{array}{c}0.012^{\text {*** }} \\
(3.1)\end{array}$ \\
\hline Intangibility ${ }_{t}$ & $\begin{array}{c}0.091 \\
(1.0)\end{array}$ & $\begin{array}{c}0.062 \\
(0.6)\end{array}$ & $\begin{array}{c}-0.041 \\
(0.9)\end{array}$ & $\begin{array}{c}0.040 \\
(1.0)\end{array}$ & $\begin{array}{l}0.033 \\
(1.0)\end{array}$ & $\begin{array}{c}0.107^{* *} \\
(3.1)\end{array}$ & $\begin{array}{c}0.057^{* *} \\
(1.6)\end{array}$ \\
\hline EFWAMB $_{t}$ & $\begin{array}{l}0.028 \\
(1.8)\end{array}$ & $\begin{array}{c}0.059^{* * *} \\
(4.1)\end{array}$ & $\begin{array}{c}0.025 \\
(1.1)\end{array}$ & $\begin{array}{c}0.015 \\
(0.7)\end{array}$ & $\begin{array}{c}-0.001 \\
(0.0)\end{array}$ & $\begin{array}{c}-0.003 \\
(0.1)\end{array}$ & $\begin{array}{c}0.020 \\
(1.1)\end{array}$ \\
\hline EFWAMB $_{\mathrm{t}} \times \mathrm{D}^{\mathrm{ICT}}$ & $\begin{array}{c}-0.152^{* *} \\
(2.6)\end{array}$ & $\begin{array}{c}-0.008 \\
(0.1)\end{array}$ & $\begin{array}{c}-0.007 \\
(0.1)\end{array}$ & $\begin{array}{c}-0.120 \\
(1.8)\end{array}$ & $\begin{array}{c}-0.096 \\
(1.4)\end{array}$ & $\begin{array}{c}-0.051 \\
(0.8)\end{array}$ & $\begin{array}{c}-0.056 \\
(1.0)\end{array}$ \\
\hline $\mathrm{D}^{\mathrm{ICT}}$ & $\begin{array}{l}0.080 \\
(0.9)\end{array}$ & $\begin{array}{l}0.018 \\
(0.1)\end{array}$ & $\begin{array}{c}0.019 \\
(0.3)\end{array}$ & $\begin{array}{c}0.139 \\
(1.9)\end{array}$ & $\begin{array}{l}0.112 \\
(1.4)\end{array}$ & $\begin{array}{c}0.045 \\
(0.6)\end{array}$ & $\begin{array}{l}0.077 \\
(1.2)\end{array}$ \\
\hline \# observations & 386 & 514 & 584 & 622 & 630 & 619 & 1195 \\
\hline \# firms & 125 & 148 & 156 & 160 & 161 & 164 & 165 \\
\hline Pseudo $\mathrm{R}^{2}$ & 0.069 & 0.078 & 0.057 & 0.045 & 0.058 & 0.093 & 0.086 \\
\hline Wald test & $56.8^{* * *}$ & $145.8^{* *}$ & $116.6^{* *}$ & $107.8^{* * *}$ & $125.1^{* * *}$ & $180.7^{* *}$ & $192.4^{* *}$ \\
\hline Common AR(1) & & & & & & & \\
\hline Coefficient & 0.66 & 0.97 & 0.73 & 0.69 & 0.65 & 0.70 & 0.74 \\
\hline
\end{tabular}




\begin{tabular}{|c|c|c|c|c|c|c|c|}
\hline \multicolumn{8}{|l|}{ App. B (continued) } \\
\hline & $\begin{array}{c}1993- \\
1996\end{array}$ & $\begin{array}{c}1994- \\
1997\end{array}$ & $\begin{array}{c}1995- \\
1998\end{array}$ & $\begin{array}{c}1996- \\
1999\end{array}$ & $\begin{array}{l}1997- \\
2000 \\
\end{array}$ & $\begin{array}{l}1998- \\
2001\end{array}$ & $\begin{array}{c}\text { Full } \\
\text { sample }\end{array}$ \\
\hline \multicolumn{8}{|l|}{ Continental Europe } \\
\hline Profitability ${ }_{t}$ & $\begin{array}{c}-0.587^{* *} \\
(13.4)\end{array}$ & $\begin{array}{l}-0.713^{* *} \\
(17.9)\end{array}$ & $\begin{array}{c}-0.590^{* *} \\
(19.3)\end{array}$ & $\begin{array}{c}-0.627^{* *} \\
(15.9)\end{array}$ & $\begin{array}{l}-0.596^{* *} \\
(16.1)\end{array}$ & $\begin{array}{l}-0.598^{* *} \\
(15.3)\end{array}$ & $\begin{array}{c}-0.572^{* *} \\
(18.6)\end{array}$ \\
\hline Size $_{t}$ & $\begin{array}{l}0.026^{* *} \\
(22.3)\end{array}$ & $\begin{array}{c}0.019^{* * *} \\
(17.5)\end{array}$ & $\begin{array}{l}0.023^{* *} \\
(25.9)\end{array}$ & $\begin{array}{l}0.022^{* *} \\
(16.3)\end{array}$ & $\begin{array}{l}0.024^{* *} \\
(16.0)\end{array}$ & $\begin{array}{l}0.022^{* * *} \\
(16.8)\end{array}$ & $\begin{array}{l}0.026^{* * *} \\
(18.8)\end{array}$ \\
\hline Interest rate ${ }_{t}$ & $\begin{array}{c}-0.138^{* *} \\
(6.4)\end{array}$ & $\begin{array}{c}-0.154^{* * *} \\
(9.4)\end{array}$ & $\begin{array}{c}-0.179^{* * *} \\
(9.9)\end{array}$ & $\begin{array}{c}-0.161^{* *} \\
(8.9)\end{array}$ & $\begin{array}{c}-0.152^{* *} \\
(7.8)\end{array}$ & $\begin{array}{c}-0.112^{* * *} \\
(5.6)\end{array}$ & $\begin{array}{l}-0.142^{* * *} \\
(10.7)\end{array}$ \\
\hline Market-to-book ${ }_{t}$ & $\begin{array}{c}-0.009^{*} \\
(2.0)\end{array}$ & $\begin{array}{c}-0.008^{*} \\
(2.2)\end{array}$ & $\begin{array}{c}-0.003 \\
(1.0)\end{array}$ & $\begin{array}{c}-0.002 \\
(0.7)\end{array}$ & $\begin{array}{c}0.001 \\
(0.6)\end{array}$ & $\begin{array}{c}0.001 \\
(0.4)\end{array}$ & $\begin{array}{c}-0.001 \\
(0.5)\end{array}$ \\
\hline Intangibility ${ }_{\mathrm{t}}$ & $\begin{array}{c}0.095^{* *} \\
(3.5)\end{array}$ & $\begin{array}{c}0.064^{* * *} \\
(3.3)\end{array}$ & $\begin{array}{c}0.109^{* * *} \\
(5.6)\end{array}$ & $\begin{array}{l}0.016 \\
(1.1)\end{array}$ & $\begin{array}{l}0.012 \\
(0.6)\end{array}$ & $\begin{array}{c}-0.011 \\
(0.5)\end{array}$ & $\begin{array}{c}0.053^{* * *} \\
(2.7)\end{array}$ \\
\hline EFWAMB $_{t}$ & $\begin{array}{c}0.006 \\
(0.5)\end{array}$ & $\begin{array}{c}0.003 \\
(0.3)\end{array}$ & $\begin{array}{c}-0.006 \\
(0.5)\end{array}$ & $\begin{array}{c}0.016 \\
(1.2)\end{array}$ & $\begin{array}{c}0.023 \\
(1.8)\end{array}$ & $\begin{array}{c}0.003 \\
(0.2)\end{array}$ & $\begin{array}{c}0.002 \\
(0.2)\end{array}$ \\
\hline EFWAMB $_{\mathrm{t}} \times \mathrm{D}^{\mathrm{ICT}}$ & $\begin{array}{c}-0.078^{*} \\
(2.0)\end{array}$ & $\begin{array}{l}0.000 \\
(0.0)\end{array}$ & $\begin{array}{c}-0.039 \\
(0.8)\end{array}$ & $\begin{array}{c}-0.063 \\
(1.2)\end{array}$ & $\begin{array}{c}-0.117^{*} \\
(2.4)\end{array}$ & $\begin{array}{c}-0.028 \\
(0.6)\end{array}$ & $\begin{array}{c}-0.079^{*} \\
(2.3)\end{array}$ \\
\hline$D^{\mathrm{ICT}}$ & $\begin{array}{c}0.049 \\
(1.2)\end{array}$ & $\begin{array}{c}-0.044 \\
(0.9)\end{array}$ & $\begin{array}{c}0.015 \\
(0.3)\end{array}$ & $\begin{array}{l}0.032 \\
(0.6)\end{array}$ & $\begin{array}{c}0.080 \\
(1.6)\end{array}$ & $\begin{array}{c}-0.008 \\
(0.2)\end{array}$ & $\begin{array}{l}0.057 \\
(1.6)\end{array}$ \\
\hline \# observations & 949 & 1152 & 1268 & 1325 & 1340 & 1312 & 2625 \\
\hline \# firms & 287 & 316 & 334 & 341 & 343 & 344 & 348 \\
\hline Pseudo $\mathrm{R}^{2}$ & 0.292 & 0.259 & 0.236 & 0.217 & 0.227 & 0.199 & 0.231 \\
\hline Wald test & $1348.8^{* *}$ & $1376.2^{* *}$ & $1321.3^{* *}$ & $1331.3^{* *}$ & $902.4^{* *}$ & $722.4^{* *}$ & $1200.9^{* * *}$ \\
\hline \multicolumn{8}{|l|}{ Common AR(1) } \\
\hline Coefficient & 0.89 & 0.80 & 0.84 & 0.80 & 0.83 & 0.76 & 0.80 \\
\hline \multicolumn{8}{|c|}{$\begin{array}{l}\text { Note: The dependent variable is leverage. } \mathrm{D}^{\mathrm{ICT}} \text { is a dummy variable that takes value } 1 \text { if the respective firm is in } \\
\text { an ICT industry and } 0 \text { otherwise. Appendix A specifies the four-digit SIC codes that we classify as ICT } \\
\text { industries. See Table } 1 \text { for variable definitions. In addition to the reported variables each regression contains a } \\
\text { year-specific constant term. Presented results derive from cross-sectional time-series FGLS regressions, } \\
\text { allowing for heteroskedastic panels and a common autoregressive coefficient for all panels. The Wald test } \\
\text { checks whether all coefficients are equal to zero. * and ** denote statistical significance at the 5\% and } 1 \% \text { level, } \\
\text { respectively. }\end{array}$} \\
\hline
\end{tabular}

